\title{
THE RELATIONSHIP BETWEEN WORKING BEHAVIOR AND THE INCIDENCE OF TYPE II DIABETES MELLITUS OF WORKERS WITH THE SNEHANDU THEORY
}

\author{
Ninin Nuryantini Farid ${ }^{1}$, Bagus Pratama Suwardono ${ }^{1}$ \\ ${ }^{1}$ Department of Health Promotion and Behavioral Science \\ Faculty of Public Health, Airlangga University, Surabaya, Indonesia \\ Correspondence address: Ninin Nur Yantini Farid \\ E-mail: yantidwi95@gmail.com
}

\begin{abstract}
There are two types of Diabetes Mellitus (DM), namely Type I DM and Type II DM. Type II DM is caused by the inability of the body to respond to insulin that is produced by the pancreas, thus resulting in an increase in blood glucose levels. Eleven out of twenty workers at the Faculty of Public Health, Universitas Airlangga suffered from Type II DM. Observational research with a quantitative approach was conducted through a cross-sectional approach. The population selected was 89 workers at the faculty. The samples were randomly selected with the characteristics of having more than 45 years of age. There were significant variables between working behavior and the incidence of Type II DM including work, last education, and social support. Furthermore, there were insignificant variables between working behavior and the incidence of Type II DM including gender, age, family members, frequency of exercise, behavior intention, personal autonomy, accessibility to information, and action situation. In conclusion, individual's latest education, employment, and social support had a significant relationship with exercise behavior and the incidence of Type II DM.
\end{abstract}

Keywords: physical exercise, diabetes mellitus, wokers at FKM Universitas Airlangga

\section{INTRODUCTION}

Diabetes Mellitus (DM) is categorized as the complex and chronic disease because it requires medical attention to control blood sugar (Soegondo, 2015). Diabetes mellitus is divided into two types, namely Type I DM and Type II DM. Type I DM causes abnormal insulin production due to damage of the pancreatic beta cells. One of the characteristics of Type I DM is that insulin is not produced according to the needs of the individual's body due to genetic factors from birth (Soegondo, 2015).

Meanwhile, Type II DM is a condition where the body cannot absorb insulin effectively (N.G. and N.J. 2019). This is due to an unhealthy lifestyle, i.e., a lack of physical activity, smoking and poor psychological conditions (Soegondo, 2015). According to all categories of DM sufferers whose age is between 45-60 years, 90-95\% of them suffer from Type II DM. However, the trend began to shift to productive ages as there was a significant increase in the prevalence rate of DM from $6.9 \%$ in 2013 to $8.5 \%$ in 2018 , or it reached more than 16 million people (Indonesian Ministry of Health, 2018). Humans in general will experience a drastic physiological decline after the age of 40 (Muslim, 2018).

Moreover, families who have a history of Type II DM also have a greater risk of 5-10 times of becoming diabetic (Smeltzer, 2007). Additionally, an unstable psychological condition has an influence on the dietary consumption of individuals and causes them to consume high-glucose foods. It increases the body's metabolism and energy demand, which causes the pancreas to work harder and decreases the production of insulin (Smeltzer, 2007).

Based on the International Federation of Diabetes (IDF) (2017), in 2014 , the prevalence rate of DM was $8.3 \%$ of all populations in the world and increased to 387 million sufferers. In Southeast Asia, there were 81 million people who suffer from DM. The number of people with DM was estimated to continue to increase from 
$7 \%$ among those aged $20-79$ years in 2010; it will increase to $8.4 \%$ in 2030 (World Health Organization, 2015). Indonesia is in the 5th position for the highest population of DM sufferers after China, India, America, and Brazil, with a total of $5.81 \%$ of the population suffering from DM (International Federation of Diabetes (IDF), 2017).

Based on data from the Indonesian Basic Health Research (2013), 30.4\% of people with DM were diagnosed, and $69.6 \%$ of people were free from DM. Of the total population amounting to $176,689,336$ individuals, a proportion of DM sufferers over 15 years old was at $6.9 \%$. Moreover, $93.1 \%$ of the population were undiagnosed for DM. The data of Indonesian Basic Health Research (2013) also stated that $1.1 \%$ DM sufferers were between 15-24 years old; $2.7 \%$ between $25-34$ years old; $6.1 \%$ between $35-44$ years old; $9.7 \%$ between $45-54$ years old; $11.5 \%$ between 55-64 years old; $13.2 \%$ between $65-74$ years old; and $13.20 \%$ between 75 years and over (Basic Health Research, 2013). The data indicated that the number of DM sufferers increased with age. This is directly proportional to the statement from the Indonesian Society of Endocrinology (2011) who stated that people over 45 years of age will experience increasing glucose intolerant to age. This is due to changes in the body's composition, decreased physical activity, decreased tissue sensitivity to insulin, or combination of the above to body aging (Iglay et al., 2007).

The Basic Health Research (2013) mentioned DM is more likely to be suffered by women as their risk of obtaining DM is $7.7 \%$, while for men is $5.6 \%$. This is supported by Irawan's research (2010) which states that women had a high risk for DM as a woman's body is prone to a larger increase in body mass index compared to men. Women who have gone through menopause or post menopause undergo premenstrual syndrome, which causes them to experience the spread of fat in the body. The spread of fat in the body can easily be accumulated because of hormonal processes and puts women at a high risk of suffering from DM. In Indonesia, 17.9 million people were at risk of suffering from DM. Meanwhile, there were 10 million people with DM in Indonesia (Basic Health Research, 2013). The East Java province was in the 10th place for the prevalence of DM sufferers in Indonesia. Surabaya was among the 9 cities for having a prevalence of $6.8 \%$ DM sufferers of the population in 2012 or as many as 21,262 people (Basic Health Research, 2013).

Workers in Surabaya have dense working hours that are on average around 8.5 hours/day, which causes workers to skip breakfast and physical activities (Fauzia, Sari and Artini, 2013). Guidelines regarding working hours are regulated in the Mayor of Surabaya's Regulation Number 21 of 2006 concerning Working Days and Hours for Agencies in Surabaya. The guidelines state that the effective hours of the week are from $07.30 \mathrm{am}-04.00 \mathrm{pm}$ with a break from 12.00 am-12.30 pm on Monday to Thursday and from $07.30 \mathrm{am}-03.00 \mathrm{pm}$ with a break from $11.00 \mathrm{am}-01.00 \mathrm{pm}$ on Friday. Saturday and Sunday are holidays, and thus most workers cannot exercise 3-4 times a week. Based on the age group, according to Prasetyo's study (2005), less than $70 \%$ of individuals for the 5-19 age group exercised, while less than $20 \%$ of those aged 20-60 years did exercise. This showed that there was a decrease in exercise activity at the age of 20 years. Further, the percentage of DM sufferers by occupation was at $5.8 \%$ per 12,191 individuals (Basic Health Research, 2013).

The health data on employees of the Faculty of Public Health, Universitas Airlangga shows that 11 out of 20 workers suffered from DM in 2017 as recorded in the Integrated Development Post (FKM UA POSBINDU) Book. Besides, there were 8 female workers and 3 male ones who suffered from DM according to their fasting blood pressure. According to the World Health Organization (2015), blood sugar levels should be less than 110 for normal 
fasting, for pre-diabetes mellitus 110-125, and for DM more than 126. This is confirmed by Jelantik and Haryati (2014) by stating that DM often affected more women because they tended to have more low-density lipoprotein (LDL) (which is often called "bad cholesterol"), higher triglycerides, and lower physical activities than men.

According to Willett et al (2002), exercise and proper diet can affect the increase in DM cases in obese individuals. Therefore, it is advised for people with DM to exercise for 150 minutes/week. Sports activities that can be done include moderate aerobics (maximizing the heart to 50-70\%) and heavy aerobics for approximately 90 minutes/week maximizing the heart by more than $70 \%$ and being conducted in 3-4 sessions per week (The Indonesian Society of Endocrinology, 2011).

Physical activity or exercise is the most influential activity towards the successful management of DM (Utomo, A.Y.S and Julianti, H.P, 2011, 2011). The Faculty of Public Health, Universitas Airlangga has carried out physical activities such as gymnastics every Friday, but both employees and educators rarely participate in the agenda. Besides, the duration of physical activity is not appropriate as it should be 3-4 times a week. Exercise is an important factor in DM handling as it also maintains body weight, helps improve insulin function in the body, keeps blood pressure normal, and improves psychological well-being (American Diabetes Association, 2014). This is also supported by the research of Fauzia, Sari and Artini (2013) which found that out of a total of 147 samples with DM, less than $50 \%$ exercised because of managing DM. Human health behavior such as exercise has many influencing factors, both internal and external (Notoatmodjo, 2012).

Apart from exercise, dietary patterns are also important for managing Type II DM, for example, by not consuming excess fat, sugar, having breakfast before 9 o'clock, and eating fruits and vegetables
(Indonesian Ministry of Health, 2014). Dewi (2013) declared that inadequate consumption of fruits and vegetables causes less intake of fiber and magnesium, leading to Type II DM. Moreover, fat consumption can increase more than $25 \%$ of fat content in the blood (Indonesian Ministryof Healthc, 2014).

Based on the theoretical analysis, Snehandu B. Kar stated that healthy behavior is influenced by a person's intention to act (behavior intention), social support, information, and facilities for health (accessibility to information), personal autonomy in decision making and action, and the possibility of individual to act in a certain context (action situation). Therefore, this study aimed to analyze a relationship between exercise behavior and the incidence of Type 2 DM among workers at the Faculty of Public Health, Universitas Airlangga.

\section{METHODS}

This study was conducted at the Faculty of Public Health, Universitas Airlangga, Surabaya, in May to June 2018. It was an observational study with a quantitative method and used a crosssectional approach. Primary data were obtained through interview and questionnaires sent directly to respondents. The population was 89 workers over 45 years old at the Faculty of Public Health, Universitas Airlangga, Surabaya. The number consisted of staff and lecturers. Then, 48 samples were obtained by using the Slovin simple random sampling technique when the population was homogenous and had the same chance. The criteria of the samples were divided into 2 , namely inclusion and exclusion. The inclusion criteria for the respondents were workers over 45 years old, actively working, not sick, and willing to be interviewed. Meanwhile, the exclusion criteria for them were those less than 45 years old, not actively working, sick, and unwilling to be interviewed. 
The independent variables used were worker characteristics, worker exercise intentions and worker social support. The workers also answered the questionnaire with the categories of strongly agree, agree, neutral, disagree, and strongly disagree. The variables of access to worker information and knowing workers' decisions were discovered in the questionnaire with yes and no categories. While the dependent variable included exercise behavior among the workers.

This study used a descriptive analysis and statistical analysis. The statistical analysis was conducted to determine whether there was a relationship between the research variables. Further, the research test used Chi-square to determine the existence of a relationship between research variables. A significance result of less than 0.05 suggested a relationship, while no significant relationship would result in a score of more than 0.05. Data management was performed in editing, scoring and tabulating processes. Editing was done to complete each questionnaire and ensure that all of the questions were answered, otherwise it was necessary to recollect data from the respondents. Scoring was done to assess each value to measure the ability of the respondents. Tables were also created according to the required analysis. Before being conducted, this study passed the ethics review with the ethical number: 211-KEPK.

\section{RESULTS}

The distribution of the respondents was based on several categories such as age, family members, gender, latest education, and employement status. The calculations from 48 samples at the Faculty of Public Health, Universitas Airlangga, are explained in this section.

Table 1 shows that the age range of respondents at the Faculty of Public Health, Universitas Airlangga, had an average age of 41-60 years. Ages of above 40 years fall in the middle-age category, while those aged 60-70 years are categorized as elderly (World Health Organization, 2007). This shows that the workers were classified middle aged and elderly.

Table 1. Frequency Distribution of Respondents by Age in 2018

\begin{tabular}{ccc}
\hline Age Range & Total & Percentage \\
\hline $11-20$ & 0 & $0 \%$ \\
$21-30$ & 0 & $0 \%$ \\
$31-40$ & 0 & $0 \%$ \\
$41-50$ & 20 & $41.67 \%$ \\
$51-60$ & 20 & $41.67 \%$ \\
$\geq 60$ & 8 & $16.66 \%$ \\
\hline Total & $\mathbf{4 8}$ & $\mathbf{1 0 0 \%}$ \\
\hline
\end{tabular}

Table 2. Frequency Distribution of Respondents by Family Member in 2018

\begin{tabular}{ccc}
\hline $\begin{array}{c}\text { Family } \\
\text { members }\end{array}$ & Total & Percentage \\
\hline$\leq 3$ & 13 & $27.08 \%$ \\
$\geq 4$ & 35 & $72.92 \%$ \\
\hline Total & $\mathbf{4 8}$ & $\mathbf{1 0 0 \%}$ \\
\hline
\end{tabular}

Regarding family members, Table 2 indicates that the majority of the respondents had > 4 family members (72.92\%). However, in regards to this study, it is not only the quantity but the quality of family members that can affect the reminders between family members.

Table 3. Frequency Distribution of Respondent by Gender in 2018

\begin{tabular}{ccc}
\hline Gender & Total & Percentage \\
\hline Male & 26 & $54.17 \%$ \\
Female & 22 & $45.83 \%$ \\
\hline Total & $\mathbf{4 8}$ & $\mathbf{1 0 0 \%}$ \\
\hline
\end{tabular}

Viewed from gender, the distribution of respondents was not significantly different; there were $54.17 \%$ males and $45.83 \%$ females. Based on several studies, men may have a higher risk for developing DM (L'Heveder and Nolan, 2013). Meanwhile, women may have a higher risk of suffering from DM (Alghadir 
et al., 2014). These opposing views may result from differences in the number or condition of the respondents in each study.

Table 4. Frequency Distribution of Respondents by Lastest Education in 2018

\begin{tabular}{lcc}
\hline Lastest education & Total & Percentage \\
\hline No school & 0 & $0 \%$ \\
Elementary school & 0 & $0 \%$ \\
Junior high school & 0 & $0 \%$ \\
High school & 11 & $22.92 \%$ \\
Associate Degree 3 & 0 & $0 \%$ \\
Bachelors & 10 & $20.83 \%$ \\
Masters & 9 & $18.75 \%$ \\
Doctorates & 18 & $37.50 \%$ \\
\hline \multicolumn{1}{c}{ Total } & $\mathbf{4 8}$ & $\mathbf{1 0 0 \%}$ \\
\hline \multicolumn{1}{c}{}
\end{tabular}

For the latest education, the majority of respondents obtained their Doctorate Degree $(37.50 \%)$, followed by high school $(22.92 \%)$. Therefore, when dealing with $\mathrm{DM}$, there is no similarity in perceptions due to different levels of education.

Table 5. Frequency Distribution of Respondents by Occupation in 2018

\begin{tabular}{|c|c|c|c|}
\hline $\begin{array}{c}\text { Employe } \\
\text { ment }\end{array}$ & $\begin{array}{c}\text { Suffering } \\
\text { from } \\
\text { Diabetes }\end{array}$ & $\begin{array}{c}\text { Not } \\
\text { Suffering } \\
\text { from } \\
\text { Diabetes }\end{array}$ & $\%$ \\
\hline \multirow{2}{*}{$\begin{array}{l}\text { Teacher } \\
\text { Employe } \\
\text { es }\end{array}$} & 9 & 16 & \multirow{2}{*}{$\begin{array}{l}52.8 \% \\
47.2 \%\end{array}$} \\
\hline & 17 & 6 & \\
\hline Total & & & $100 \%$ \\
\hline
\end{tabular}

Table 6. Frequency Distribution of Respondents by Frequency of Exercise in 2018

\begin{tabular}{lcc}
\hline $\begin{array}{c}\text { Exercise } \\
\text { Frequency }\end{array}$ & Total & Percentage \\
\hline Often & 13 & $27.08 \%$ \\
Rarely & 21 & $43.75 \%$ \\
Never & 14 & $29.17 \%$ \\
\hline \multicolumn{1}{c}{ Total } & $\mathbf{4 8}$ & $\mathbf{1 0 0 \%}$ \\
\hline
\end{tabular}

There were 26 workers who suffered from DM. Employees suffered from DM more than educators. This is related to knowledge and a work environment that can affect their healthy lifestyle.

Based on frequency of exercise, Table 6 shows that the majority of them or around $43.75 \%$ did sports 1-2 times per week. According to the respondents who rarely did sports, they usually fulfilled their exercise needs by participating in gymnastics every Friday at the Faculty of Public Health, Universitas Airlangga.

Table 7. Frequency Distribution of Respondents by Intention to Exercise in 2018

\begin{tabular}{ccc}
\hline $\begin{array}{c}\text { Intention to } \\
\text { Exercise }\end{array}$ & Total & Percentage \\
\hline Good & 23 & $47.92 \%$ \\
Bad & 25 & $52.08 \%$ \\
\hline Total & $\mathbf{4 8}$ & $\mathbf{1 0 0 \%}$ \\
\hline
\end{tabular}

Regarding behavior intention (intention to exercise), $47.92 \%$ of the respodnents had the intention to exercise (see Table 7).

Table 8. Frequency Distribution of Respondents by Social Support in 2018

\begin{tabular}{ccc}
\hline $\begin{array}{c}\text { Social } \\
\text { Support }\end{array}$ & Total & Percentage \\
\hline Good & 30 & $62.50 \%$ \\
Bad & 18 & $37.50 \%$ \\
\hline Total & $\mathbf{4 8}$ & $\mathbf{1 0 0 \%}$ \\
\hline
\end{tabular}

In terms of social support from family, co-workers, close friends, and people around them, the majority of workers received good social support $(62.50 \%)$. This showed that information and emotional support can influence individuals to behave positively because of legitimacy or recognition from those around them. 
Table 9. Frequency Distribution of Respondents by Accessibility to Facilities and Information in 2018

\begin{tabular}{ccc}
\hline $\begin{array}{c}\text { Accessibility to } \\
\text { Facilities and } \\
\text { Information }\end{array}$ & Total & Percentage \\
\hline Good & 15 & $31.25 \%$ \\
Bad & 33 & $68.75 \%$ \\
\hline Total & $\mathbf{4 8}$ & $\mathbf{1 0 0 \%}$ \\
\hline
\end{tabular}

Table 9 illustrates that the accessibility to facilities and information among the respondents was still low. As many as $68.75 \%$ of the respondents did not have access to facilities and information. Access to information related to sports and ease of exercising outside and within the office can affect an individuals' exercise behavior.

Table 10. Frequency Distribution of Respondents by Personal Freedom in 2018

\begin{tabular}{ccc}
\hline $\begin{array}{c}\text { Personal } \\
\text { Decision }\end{array}$ & Total & Percentage \\
\hline Good & 7 & $14.59 \%$ \\
Bad & 41 & $85.41 \%$ \\
\hline Total & $\mathbf{4 8}$ & $\mathbf{1 0 0 \%}$ \\
\hline
\end{tabular}

Table 10 shows that personal autonomy of the respondents was still low $(14.59 \%)$. This showed that the level of education did not guarantee the making of good personal decisions. Personal decisions can affect the level of individual compliance with choosing an action.

Table 11. Frequency Distribution of Respondents by Possible Conditions in 2018

\begin{tabular}{ccc}
\hline $\begin{array}{c}\text { Possible } \\
\text { Conditions }\end{array}$ & Total & Percentage \\
\hline Good & 24 & $50.00 \%$ \\
Bad & 24 & $50.00 \%$ \\
\hline Total & $\mathbf{4 8}$ & $\mathbf{1 0 0 \%}$ \\
\hline
\end{tabular}

For situation factors, situations that allowed the respondents to prevent the incidence of DM reached $50.00 \%$.

\section{DISCUSSION \\ Respondents' Age}

The results of the Chi-Square test for age was 0.695 , suggesting no significant association with the incidence of DM. The average human physical ability decreases after the age of 40 years (Maryani, 2010). Being overweight at the age of 45 years will further increase the chance of suffering from DM as it is related to the body's insensitivity to insulin. The result of this study is not in line with research conducted by Widiantini and Tafal (2014) which found that there was a relationship between age and the incidence of DM. However, Wulan and All, (2017) stated that there was no significant relationship between age and the incidence of DM. This is reinforced by Retnowati and Satyabakti (2015) who found that the quality of life or age of DM sufferers had more impact due to chronic conditions such as complications as the main trigger.

\section{Number of Family Members}

The chi-square tes found that the number of family members had no relationship with the incidence of $\mathrm{DM}(\mathrm{p}=$ 0.222 ). The number of family members did not affect the incidence of DM, while family support did. Family support consists of the action, attitude and acceptance given by family members to their family member who suffers from the disease (Pieter and Lubis, 2010). Support is obtained from the closest people, such as parents, children, husbands, wives, and others. It can be in the form of information, attitudes, or material (financial) support that makes the individuals feel cared for and supported (Wulan and All, 2017). Hence, the quality aspect of family members through action and support will have more impact compared to the quantity of family members. 


\section{Gender Characteristics}

Sex had no relationship with the incidence of DM $(p=1.000)$, indicating that both men and women were at risk for DM. However, according to one respondent's opinion, she had less time and energy because apart from being a career woman, she also managed households without the help of an assistant. Therefore, she had less opportunities to exercise to reduce the risk of DM. A study by Herdianti (2017) also explained that there was a relationship between gender and the incidence of DM. Nevertheless, according to research by Jelantik and Haryati (2014) and Retnowati and Satyabakti (2015), there was no significant relationship between gender characteristics and the incidence of DM. Complementary diseases or complications due to DM are more negatively impactful on gender as male DM sufferers can become impotent, and women may suffer form vaginal infections (Handayani and Tandra, 2010).

\section{Education Level}

According to the chi-square results, there was a relationship between the latest education level and the incidence of DM (p $=0.037)$. Education is an experience undertaken to develop one's abilities and quality of life. If the individual's education improves, they would also be more able to utilize the knowledge they have and improve their skills (Syamsiah, 2011). Individuals with higher education are more capable of eating more nutritious and healthier food and prefer health services that prioritize prevention and medical care (Papalia, Olds and Feldman, 2009). This is in accordance with research of Cabral, Tahu and Tage (c2016), which found that there was a significant relationship between education level and the incidence of DM. One's actions will be reflected on insights she/he has as well as the cognitive domain obtained from the educational process and experience (Cabral, Tahu and Tage, 2016).

\section{Employement}

The current results found that more teaching staff experienced DM as compared to educators. There was a relationship between work and the incidence of DM ( $p$ $=0.019)$. This result is supported by research of Mongisidi (2015) which stated that work and diabetes mellitus were allied. Grant et al. (2009) further found unemployed individuals were more at risk of developing DM due to the lack of physical activity. This has an impact on the body's metabolic processes as it does not maximize calorie burn in the body.

\section{Frequency of Exercise}

Frequency of exercise, in turn, did not have any relationship with the incidence of DM ( $p=0.962)$. The result of this study is supported by Damayanti's study (2015) which stated that physical activity was not significantly related to the incidence of DM and components of the blood glucose metabolic syndrome. Conversely, Kriska, Hawkins and Richardson (2008) concluded that if a person did more activities such as exercising, blood glucose levels could be lower. The differences in previous studies may be the result of physical activities that meets the standards of frequency, duration, intensity, and types of activity.

\section{Behavior Intention}

The chi-square test also displayed no relationship between self-intention and diabetes incidence $(p=1.000)$. Intention is a tendency to choose or not to do something, in which individuals have full authority over their decisions (Ajzen, 2005). Previous research from Haskas (2018) also stated that there was no relationship between intention and DM control.

\section{Social Support}

The results indicated that there was a relationship between social support and the incidence of DM $(p=0.004)$. Social support may involve financial support, 
information support, emotional support, and others. Besides, previous research from Akoit (2015) also stated that social support could help individuals who suffered from DM to control more their condition. Likewise, if the social support is low, it will also have an impact on the individual's physical activity (Akoit, 2015). It can also be concluded that a lack of social support in the surrounding environment results in a lack of attention to perform sports or physical activity, leading to a greater risk for DM.

\section{Accessbility to Information}

The chi-square test results showed no relationship between the accessbility to facilities and information with the incidence of DM ( $p=0.310)$. The result of this study is not in accordance with the statement from Rosa (2015), which found that information support i.e., giving advice and disseminating information was considered as assistance by families. Information becomes a factor that influences knowledge and cognition to form individual actions/behaviors. Different results on this variable may be caused by differences in the level of education which influences information acceptance and different economic affordability in each individual.

\section{Personal Autonomy}

There was no relationship between personal decision and the incidence of DM $(p=0.223)$. Self-control will influence decision making to carry out a behavior that is purely of its will without the influence of others (Evans et al. 2013). Hagger et al. (2013)vity and diet. The different results may be caused by differences in education levels. The lower the level of education, the more likely low the self-control. Therefore, it may be easier for people to be influenced by other parties.

\section{Actionable Situations}

The study indicated that there was no relationship between possible actionable situations and the incidence of DM ( $\mathrm{p}=$ 0.772). Research of Essy Phitri et al. (2013) stated that an attitude by itself could not be manifested in the form of action. Even though the individual had sufficient knowledge, it could not ensure a positive change in attitude. Attitudes, in turn, can be a closed behavior, where changes cannot necessarily be observed. Changes in attitude can be manifested by personal freedom and conditions that allow one of the facilities. A study by Ajzen (c2005) concluded an individual could feel being more able to control their behavior if receiving supporting factors rather than inhibiting factors.

\section{CONCLUSION}

The DM status of the workers at the Faculty of Public Health, Universitas Airlangga was associated with education levels and employment statuses. Meanwhile, age, family members, gender and frequency of exercise were not associated with the incidence of DM.

The chi-square tests showed several independent variables i.e., behavior intention, accessibility to information, personal autonomy, and actionable situation did not have a significant relationship with the incidence of DM,. Meanwhile, social support had an association with the incidence of diabetes mellitus.

The academic community at the Faculty of Public Health, Universitas Airlangga, can take prevention measures from DM by scheduling physical activities indoors or outdoors every day for 10 minutes. Moreover, outbound activities and family participation could be done to prevent DM and support their family members at risk of DM. Outbound activities can also address family roles in DM selfmanagement.

\section{REFERENCES}

Achmad Yoga Setyo Utomo, Hari Peni Julianti, D. P. (2011) 'Hubungan 
Antara 4 Pilar Pengelolaan Diabetes Melitus dengan Keberhasilan Pengelolaan Diabetes Melitus Tipe 2.', Artikel Karya Ilmiah.

Ajzen, I. (2005) 'Attitudes, Personality and Behaviour', in Mapping Social Psychology, pp. 1-178. doi: 10.1037/e418632008-001.

Akoit, E. E. (2015) 'Dukungan Sosial Dan Perilaku Perawatan Diri Penyandang Diabetes Melitus Tipe 2', Keperawatan, 14(2), pp. 952-966.

Alghadir, A. et al. (2014) 'Diabetes risk 10 years forecast in the capital of Saudi Arabia: Canadian diabetes risk assessment questionnaire (CANRISK) perspective', Biomedical Research (India).

Association, A. D. (2014) 'Diagnosis and Classification of Diabetes Mellitus', Diabetes Care, 37(1), pp. 581-590. doi: $10.2337 / \mathrm{dc} 14-\mathrm{S} 081$.

Cabral, E. D. D., Tahu, S. K. and Tage, P. K. (2016) 'Modus Adaptasi Pasien Diabetes Mellitus Terhadap Penyakit Yang Di Derita Dengan Pendekatan Konsep Model Sisiter Calista Roy', CHM-K Health Journal.

Damayanti, S. (2015) 'Senam Diabetes Mellitus Dengan Kadar Gula Darah, Kadar Kolesterol Dan Tekanan Darah Pada Klien Diabetes Mellitus Tipe 2 Di ..., Medika.Respati.Ac.Id, 10(April).

Dasar, R. K. (2013) 'Badan Penelitian dan Pengembangan Kesehatan', Laporan Nasional 2013, pp. 1-384. doi: 1 Desember 2013.

Dewi, R. (2013) 'Faktor Risiko Perilaku yang Berhubungan dengan Kadar Gula Darah pada Penderita Diabetes Melitus Tipe 2 di RSUD Kabupaten Karanganyar', Jurnal Kesehatan Masyarakat, 2(1), pp. 118-128..

Essy Phitri, H. et al. (2013) 'Hubungan Antara Pengetahuan Dan Sikap Penderita Diabetes Mellitus Dengan Kepatuhan Diet Diabetes Mellitus Di Rsud Am. Parikesit Kalimantan Timur', Mei, 1(1), pp. 58-74.
Evans, M. et al. (2013) 'Health-related quality of life associated with daytime and nocturnal hypoglycaemic events: A time trade-off survey in five countries', Health and Quality of Life Outcomes. doi: 10.1186/1477-752511-90.

Fauzia, Y., Sari, E. and Artini, Bu. (2013) 'Gambaran Faktor-Faktor Yang Mempengaruhi Kepatuhan Diet Penderita Diabetes Mellitus Di Wilayah Puskesmas Pakis Surabaya', Keperawatan, 4(2).

Grant, J. F. et al. (2009) 'Gender-specific epidemiology of diabetes: A representative cross-sectional study', International Journal for Equity in Health, 8. doi: 10.1186/1475-9276-86.

Hagger, M. S. et al. (2013) 'Chronic Inhibition, Self-Control and Eating Behavior: Test of a "Resource Depletion" Model', PLoS ONE, $8(10)$. doi: 10.1371/journal.pone.0076888.

Handayani, O. and Tandra, H. (2010) 'Pattern of type 2 diabetes mellitus in Surabaya, Indonesia', Endocrine abstracts, 22, p. 308.

Haskas, Y. (2018) 'Variabilitas locus of control pada pasien diabetes mellitus tipe II', Variabilitas Locus of Control Pada Pasien Diabetes Mellitus Tipe Ii, 12(locus of control), pp. 358-361.

Herdianti, H. (2017) 'Determinan Kualitas Hidup Penderita Dm Tipe 2 Di Rsud Ajjappange', Jurnal Endurance, 2(1), p. 74. doi: 10.22216/jen.v2i1.1662.

Iglay, H. B. et al. (2007) 'Resistance training and dietary protein: Effects on glucose tolerance and contents of skeletal muscle insulin signaling proteins in older persons', American Journal of Clinical Nutrition, 85(4), pp. 1005-1013.

International Federation of Diabetes (IDF) (2017) 'Diabetes atlas', International Diabetes Federation., 8th edn., pp. 1150. doi: http://dx.doi. org/10.1016/S0140-6736(16)31679- 
8.

Irawan, D. (2010) Prevalensi dan Faktor Risiko Kejadian Diabetes Melitus Tipe 2 di Daerah Urban Indonesia (Analisa Data Sekunder Riskesdas 2007), Tesis.

Indonesian Ministry of Health (2018) 'Hasil Utama Riset Kesehatan Dasar Tahun 2018', Kementrian Kesehatan Republik Indonesia. doi: 1 Desember 2013.

Indonesian Ministry of Health (2014) 'WASPADA DIABETES, Eat well Live well', Pusat Data dan Informasi, pp. 2-8.

Jelantik, I. G. M. G. and Haryati, E. (2014) 'Hubungan Faktor Risiko Umur, Jenis Kelamin, Kegemukan dan Hipertensi dengan Kejadian Diabetes Melitus Tipe II di Wilayah Kerja Puskesmas Mataram', Media Bina Ilmiah39, 8(1), pp. 39-44.

Kriska, A. M., Hawkins, M. and Richardson, C. R. (2008) 'Physical Activity and the Prevention of Type II Diabetes', Current Sports Medicine Reports, 7(4), pp. 182-184. doi: 10.1249/jsr.0b013e31817ec0b4.

L'Heveder, R. and Nolan, T. (2013) 'International Diabetes Federation', Diabetes Research and Clinical Practice. $\quad$ doi: 10.1016/j.diabres.2013.08.003.

Maryani, A. H. B. R. H. (2010) 'faktorfaktor yang berhubungan dengan pola kematian pada penyakit degeneratif di indonesia', Buletin Penelitian Sistem Kesehatan -. doi: 10.1002/macp.200400177.

Mongisidi, G. (2015) 'Hubungan Antara Status Sosio-Ekonomi Dengan Kejadian Diabetes Melitus Tipe 2 Di Poliklinik Interna Blu RSUP Prof', Fakultas Kesehatan Masyarakat Universitas Sam Ratulangi.

Muslim, A. (2018) 'Korelasi Pemeriksaan Glukosa Urin Dengan Protein Urin Pada Penderita Diabetes Mellitus Tipe II di RSUD dr. H. Abdul Moeloek Provinsi Lampung', Jurnal
Kesehatan, 7(1), p. 52. doi: 10.26630/jk.v7i1.118.

N.G., F. and N.J., W. (2019) 'Epidemiology of diabetes', Medicine (United Kingdom), 47(1), pp. 22-27. doi: 10.1016/j.mpmed.2018.10.004 LK -

Notoatmodjo, S. (2012) 'Promosi Kesehatan Perilaku Kesehatan', Jakarta: Rineka Cipta, pp. 20-40.

Papalia, D. E., Olds, S. W. and Feldman, R. D. (2009) 'Human development: Perkembangan manusia, Edisi 10, Buku 2', Human development: Perkembangan manusia.

Indonesian Endocrinology Society (PERKENI) (2011) Perkumpulan Endokrinologi Indonesia. Konsensus Pengelolaan dan Pencegahan Diabetes Melitus Tipe 2 di Indonesia., Konsensus PERKENI. doi: 10.3406/arch.1977.1322.

Pieter, H. Z. and Lubis, N. L. (2010) 'Pengantar Psikologi dalam Keperawatan', in Pengantar Psikologi dalam Keperawatan.

Prasetyo, Y. (2005) Medikora: jurnal ilmiah kesehatan olahraga., MEDIKORA.

Retnowati, N. and Satyabakti, P. (2015) 'The Correlation between Family Support with the Quality of Life of Patients with Diabetes Mellitus', Jurnal Berkala Epidemiologi. doi: 10.20473/jbe.v3i12015.57-68.

Rosa, L. (2015) 'Faktor Risiko Terjadinya Ulkus Diabetikum pada Pasien Diabetes Mellitus yang Dirawat Jalan dan Inap di RSUP Dr . M . Djamil dan RSI Ibnu Sina Padang', Jurnal Kesehatan Andalas. doi: 10.1080/09654310124479.

Smeltzer, S. C. (2007) 'Buku Ajar Keperawatan Medikal Bedah Brunner \& Suddart', in Volume 3.

Soegondo, S. (2015) Penatalaksanaan Diabetes Melitus Terpadu, : FKUI. doi: 10.1002/cjce.20502.

Syamsiah, N. (2011) 'Faktor-faktor yang Berhubungan dengan Kepatuhan Pasien CKD yang Menjalani 
Hemodialisis di RSPAU Dr Esnawan Antariksa Halim Perdana Kusuma Jakarta', Tesis Universitas Indonesia, 10(2), pp. 115-123.

Widiantini, W. and Tafal, Z. (2014) 'Aktivitas Fisik, Stres, dan Obesitas pada Pegawai Negeri Sipil', Kesmas: National Public Health Journal, p. 325. doi: 10.21109/kesmas.v0i0.374.

Willett, W., Manson, J. and Liu, S. (2002) 'Glycemic index, glycemic load, and risk of type 2 diabetes', in American Journal of Clinical Nutrition.

Wilson, L. (2002) 'Patofisiologi Konsep Klinis Proses Penyakit', in Patofisiologi Konsep Klinis Proses
Penyakit.

World Health Organization (2007) WHO Global Report on Falls Prevention in Older Age., Community Health. doi: 9789241563536.

World Health Organization (2015) Commission on Ending Childhood Obesity, World Health Organization.

Wulan, M. and All, E. (2017) 'Hubungan dukungan keluarga dengan kualitas hidup Diabetes Melitus Tipe 2 Di Puskesmas Pademawu', Jurnal Berkala Epidemiologi, Volume 5 $\mathrm{N}$ (July), pp. 240-252. doi: 10.20473/jbe.v5i2.2017.240-252 